\title{
Lung Mucoepidermoid Carcinoma
}

National Cancer Institute

\section{Source}

National Cancer Institute. Lung Mucoepidermoid Carcinoma. NCI Thesaurus. Code C45544.

A lung carcinoma characterized by the presence of malignant non-keratinizing squamoid cells, mucin-producing cells and intermediate type cells. 